\title{
MENUJU DESA CERDAS PERBATASAN: SURVEY KESIAPAN DESA CERDAS
}

\section{TOWARDS A SMART VILLAGE: A READINESS SURVEY}

\author{
Syaiful Muazir1, Lestari2, M. Ridha Alhamdani3, M. Nurhamsyah4 \\ 1,2,3,4Jurusan Arsitektur, Fakultas Teknik, Universitas Tanjungpura, syaifulmuazir@teknik.untan.c.id; lestari@teknik.untan.ac.id; \\ mridhaa@teknik.untan.ac.id; nurhamsyah@teknik.untan.ac.id
}

Info Artikel:

- Artikel Masuk: 18 Desember 2019

\begin{abstract}
ABSTRAK
Untuk mengembangkan daerah perbatasan, pemerintah telah menetapkan daerah perbatasan sebagai pusat kegiatan strategis nasional. Saat ini, ada 26 pusat kegiatan strategis nasional dan sebagian besar termasuk dalam kategori daerah tertinggal dengan segala keterbatasannya. Kondisi ini membuat daerah perbatasan sulit untuk bersaing. Untuk mempercepat pembangunan desa perbatasan, salah satu konsep yang dapat digunakan adalah desa cerdas. Penelitian ini bertujuan untuk mengidentifikasi kondisi dan indikasi pilar desa cerdas di dusun Aruk (desa perbatasan). Kegiatan penelitian meliputi: (1) penilaian kesiapan literasi/melek ICT masyarakat, (2) penilaian pilar desa pintar, (3) eksplorasi potensi dan masalah, dan (4) ekspolrasi indikasi-indikasi strategi pengembangan desa cerdas. Hasil penelitian ini menemukan bahwa wilayah perbatasan telah "dibangun" melalui pendekatan pembangunan infrastruktur fisik. Indikasi "kesiapan" aplikasi desa pintar berada dalam kategori "tinggi". Dari hasil pengukuran, infrastruktur fisik dan kesiapan aparatur sipil Negara ditemukan menjadi indikator dengan skor tertinggi. Sementara itu, faktor sosial ekonomi perlu ditingkatkan. Secara keseluruhan, dusun Aruk hampir siap untuk "menerima" konsep desa pintar, dengan asumsi bahwa jika diterapkan, akan dapat meningkatkan daya saing desa melalui beberapa strategi seperti fasilitasi dan penyediaan infrastruktur.
\end{abstract}

Kata Kunci : Aruk, Desa Cerdas, Perbatasan

\begin{abstract}
To develop border areas, the government has set border areas as the center of the national strategic area. Currently, there are 26 national strategic areas and most include as categories of lagging areas with limited condition. This condition makes it difficult to compete. To accelerate border village development, one of the concepts used is a smart village. This study aims to identify the conditions and indications of smart village pillars in Aruk village (border village). The research activities include the following: (1) scoring the ICT literacy/readiness, (2) scoring the smart village pillars, (3) examining the potential and problems and (4) exploring development strategies indications. The results of this study found that the border area has been "built" through an infrastructure development approach. The indication of the "readiness" of smart village applications is in the "high" category. From measurement results, infrastructure and public service human resource was found to be the indicator with the highest score. Meanwhile, socio-economic factors need to be improved. Overall, Aruk village is almost ready to "accept" the concept of a smart village, assuming that if it is implemented, it will be able to improve village competitiveness through several strategies such as facilitation and infrastructure provision
\end{abstract}

Keyword: Aruk, Smart Village, Border

Copyright $\odot 2020$ JPWK-UNDIP This open access article is distributed under $a$ Creative Commons Attribution (CC-BY-NC-SA) 4.0 International license.

\section{PENDAHULUAN}

Berdasarkan UU Penataan ruang, terdapat kawasan strategis yang di tentukan berdasarkan kepentingan nasional. Dalam sistem perkotaan nasional, dikenal pusat kegiatan strategis nasional (PKSN) yang merupakan kawasan perkotaan yang ditetapkan untuk mendorong kawasan perbatasan Negara. Saat ini terdapat 26 PKSN diseluruh Indonesia, dan 5 diantaranya terdapat di Kalimantan Barat (Kalbar) yang 
tersebar di Paloh-Aruk (Sambas), Jagoibabang (Bengkayang), Entikong (Sanggau), Jasa (Sintang), dan Nangabadau (Kapuas Hulu). Kondisi di kawasan perbatasan Kalbar secara umum masih tertinggal dan merupakan sebaran kategori kabupaten tertinggal merujuk pada definisi kawasan tertinggal yang dikeluarkan oleh Kementerian Desa, Pembangunan Daerah Tertinggal, dan Transmigrasi (Kemendes). Hal ini disebabkan diantaranya oleh terbatasanya infrastruktur dan fasilitas-fasilitas pendukung kehidupan lainnya. Atas hal tersebut, desa-desa di kabupaten perbatasan dan tertinggal menjadi sulit untuk berdaya saing, apabila di relevansikan terhadap beberapa keterbatasan pada sektor-sektor pendukung pertumbuhan seperti laju pertumbuhan ekonomi, IPM, dan lain-lain (Kemendes, diakses Agustus 2018).

Dari penelitian sebelumnya (Muazir, 2016), didapati kecenderungan orientasi dan interaksi antara ibukota kabupaten (kota maju) dengan daerah perbatasan cenderung tidak optimal yang diakibatkan oleh beberapa faktor diantaranya jarak, keterbatasan keuangan daerah, dan luasnya wilayah pembangunan. Akibat dari tidak optimalnya hubungan tersebut, menimbulkan keterbatasan dalam "transfer" hasil-hasil pembangunan dari daerah maju ke daerah tertinggal (perbatasan). Hal menarik yang juga ditemukan adalah hubungan atau interaksi antara kota maju dengan daerah perbatasan, adalah penggunaan media teknologi/informasi yang cenderung tidak memiliki halangan dalam berkomunikasi dan berinteraksi antar wilayah. Melalui media informasi (digital), masyarakat di perbatasan dapat mengakses dan berinteraksi dengan masyarakat di wilayah lainya tanpa halangan berarti, walaupun pada kesempatan tertentu terkendala dengan infrastruktur telekomunikasi.

Kesempatan ini sejalan dengan isu-isu pengembangan kota cerdas yang memanfaatkan kompilasi data digital untuk menyediakan informasi bagi manajemen aset dan sumber daya secara efisien. Di Indonesia sendiri, konsepsi kota cerdas dan penerapannya telah dirintis, dan pada akhir tahun 2017 telah di berikan penghargaan pada kota-kota yang telah menerapkan tata kelola "cerdas" yang tentunya memberikan dampak efisiensi pada kelola pemerintahan dan kota. Selain itu, untuk menghadapi Revolusi Industri 4.0 perlu adanya usaha-usaha pendekatan "cyber-physical” yang memadukan sistem-sistem digital dan otonom dengan konektivitas terhadap pihak-pihak yang berkepentingan. Dalam pengembangannya, kota cerdas "dihipoteskan" berkorelasi dengan peningkatan daya saing (kompetitif) sebuah wilayah. Oleh penelitian Nick (2018) ia membuktikan bahwa pengembangan kota cerdas berdampak positif kuat terhadap ranking dari sebuah wilayah. Dalam penelitiannya, kriteria cerdas secara ekonomi, inovasi, pendidikan dan fleksibilitas penduduk menjadi beberapa kluster utama pendorong ranking daya saing.

Industri 4.0 diyakini sebagai pengaruh masa depan pengembangan kota atau wilayah. Pengembangan kota-kota cerdas di Indonesia semakin digalakan dan dikembangkan. Seiring dengan permasalahan daerah (desa) perbatasan, konsepsi “cerdas" tersebut diatas dapat menjadi hipotesa, pencarian, dan perumusan konsep untuk mengembangkan daya saing desa di perbatasan melalui pendekatan pembangunan "desa cerdas" yang memaksimalkan perangkat kompilasi data digital sesuai karakter wilayah untuk mengefisienkan pengelolaan terkait keterbatasan jarak dan luasan wilayah yang pada akhirnya berkolerasi dengan peningkatan daya saing. Atas beberapa pertimbangan diatas, tujuan dari artikel/penelitian ini adalah untuk mengidentifikasi "indikasi" kesiapan dan potensi dusun Aruk yang ada diperbatasan untuk menuju menjadi desa cerdas

Era moderen sekarang sering di analogikan dengan "era cerdas" (Indira et al., 2016) yang apabila di kaitkan dengan kajian wilayah, istilah kota cerdas sering didengungkan. Dilihat dari dominasi jumlah desa yang ada di Indonesia, pengembangan "desa cerdas" dapat menjadi perhatian melihat banyaknya tantangan atau masalah di desa seperti urbanisasi, ketertinggalan, dan ketimpangan standar hidup. Menurut Indira et. al (2016) pendekatan desa cerdas dapat ditekankan pada beberapa hal, seperti pada bangunan, peternakan, pertanian dan perkebunan, irigasi, kesehatan, pendidikan, dan kontrol. Beberapa penekanan tersebut dapat diaplikasikan melalui teknologi wireless, 3S, Cloud Computing, Big Data, dan RFID.

Menurut Ramachandra et al (2015) kerangka pengembangan desa cerdas harus disesuaikan dengan keterediaan sumber daya, baik alam maupun tenaga kerja, serta penerimaan sosial dari masyarakat setempat. Lanjut mereka, tahapan utama dalam pengembangan desa cerdas adalah mengetahui sumber 
daya yang ada didesa tersebut yang kemudian di implementasikan dengan intervensi teknologi yang dapat mendukung kegiatan-kegiatan pertanian, perkebunan, dan peternakan. Di katakan oleh Ahlawat (2017) konsep desa cerdas seharusnya berdasarkan atas kondisi atau lokasi geografis yang dapat memberikan gambaran ketersediaan infrastruktur dan pengaruh penggunaan teknologi terhadapnya. Penerapan desa cerdas dapat dimodelkan dengan beberapa aspek pertimbangan, yaitu kondisi permukiman, infrastruktur, sanitasi, energi, transportasi dan telekomunikasi, partisipasi publik, marketing, industri, dan peternakan. Menurut Shukla (2016) desa cerdas akan bersifat interaktif dan multi fungsi yang menggabungkan banyak orang dan kegiatan melalui media. Salah satu hal terpenting adalah adanya jaringan internet. Dengan ketersediaan internet akan menghubungkan jaringan-jaringan usaha pertanian/perkebunan antara petani dan pihak-pihak lainnya.

Dikembangkan oleh PWC (2017), pengembangan kerangka desa cerdas dapat dikembangkan melalui beberapa media yang dipertimbangkan dengan situasi dan tantangan di masing-masing desa. Secara umum terdapat 4 pilar isu/masalah pengembangan yang dapat di pertimbangkan, yaitu isu mengenai infrastruktur fisik, isu sosial, isu lingkungan, dan pemerintahan. Masing-masing pilar isu/masalah tersebut dapat di "intervensi" melalui teknologi yang dapat dikembangkan dalam beberapa bentuk seperti smart building, e-government, ehealth, smart school, dan lain-lain. Bentuk-bentuk intervensi tersebut kemudian di aplikasikan melalui state-of-art teknologi terkini seperti "perangkat" Internet of Things (IoT) dan Information and Communication Technology (ICT) yang memberikan solusi bagi masalah yang ada didesa. Dalam perencanaannya, desa cerdas sejalan dengan metodologi perencanaan kota cerdas (PWC, 2017). Merujuk pada Borsboom-Van Beurden dkk (2017) dan PwC (2017), beberapa langkah umum dalam merencanakan kota cerdas setidaknya memuat beberapa tahapan, yaitu:

1. Identifikasi isu dan permasalahan geografis

2. Eksplorasi trend dan kecenderungan penggunaan teknologi

3. Kesempatan jenis intevensi teknologi yang dapat dikembangkan

4. Menentukan tujuan dan sasaran pengembangan

5. Identifikasi kebijakan yang ada

6. Pengembangan (alternatif) rencana awal

7. Konsultasi dengan pihak-pihak yang terkait

\section{METODE}

Penelitian dilakukan di lokasi/kasus pada desa perbatasan di wilayah Kalbar, yang terletak di Dusuk Aruk, Desa Sebunga. Di Kalbar terdapat 5 Kabupaten yang berbatasan langsung dengan Sarawak, Malaysia. Untuk penelitian ini, menggunakan studi kasus yang ada di Kabupaten Sambas, Kecamatan Sajingan Besar (Dusun Aruk yang merupakan lokasi PLBN Aruk). Pengumpulan data dilakukan melalui beberapa cara, seperti observasi, wawancara, serta penyebaran kusioner terhadap penduduk yang ada di Dusun Aruk. Jumlah responden disesuaikan dengan pustaka (Krejcie and Morgan, 1970) yang disesuaikan kembali dengan kesediaan Responden di lapangan. Survey dilakukan terhadap 233 Responden (masyarakat) dan 21 Responden perangkat desa. Setelah data didapat, analisis dan pembahasan dilakukan melalui beberapa langkah dibawah ini:

1. Mengembangkan indikator pilar desa cerdas melalui pustaka-pustaka terkait. Dari beberapa pustaka (daftar pustaka), indikator pilar desa cerdas dikembangkan melalui beberapa penilaian, antara lain fisik/infrastruktur, energi, drainase dan sanitasi, sosial dan ekonomi, lingkungan, masyarakat dan pemerintahan, serta kompetensi ICT

2. Melakukan skoring/pembobotan "kesiapan" desa cerdas terhadap indikator-indikator desa cerdas seperti diatas. Penilaian berdasarkan atas kondisi eksisting di lokasi yang kemudian disesuaikan dengan bobot nilai tertentu. Penilaian dilakukan dengan membuat tingkat nilai (bobot dan skor) dari 3-1 berdasarkan kondisi yang paling sesuai sampai kondisi yang tidak sesuai 
3. Melakukan pemetaan SWOT desa perbatasan sesuai dengan hasil skoring desa cerdas, sehingga menghasilkan atau dapat diketahuinya kekuatan dan kelemahan umum desa perbatasan menuju desa cerdas

4. Eksplorasi tren dan kecenderungan penggunaan teknologi, khususnya ICT melalui pendekatan pustaka yang mengeskpolrasi kemungkinan-kemungkinan intervensi teknologi sebagai solusi pemecahan permasalahan.

5. Mengidentifikasi kesempatan pengembangan desa cerdas melalui kesesuaian kondisi dengan tren atau kecenderungan yang ada.

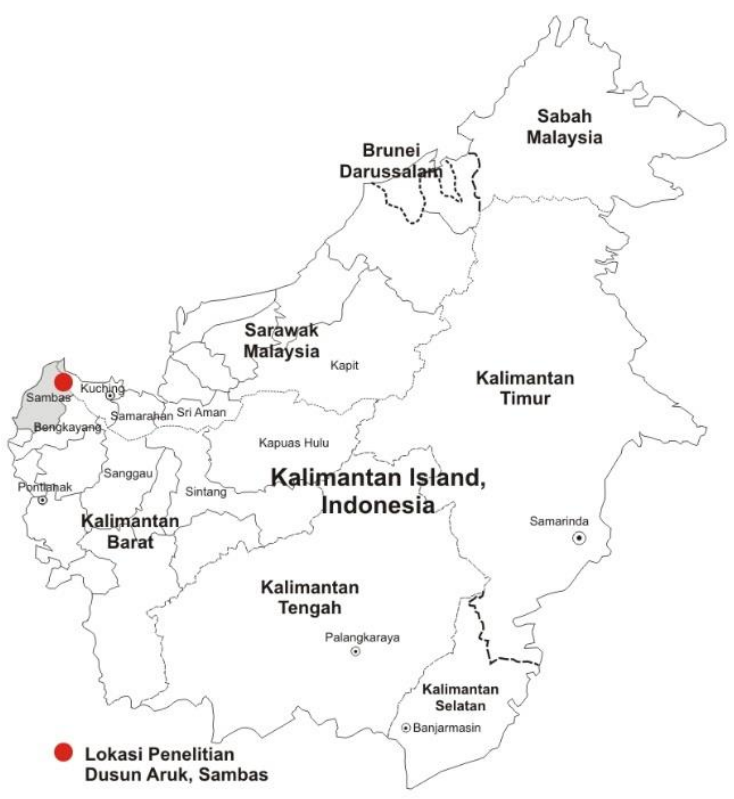

Sumber: Penulis, 2019

\section{Gambar 1. Lokasi Penelitian}

\section{HASIL DAN PEMBAHASAN}

\section{Profil Desa Perbatasan (Dusun Aruk)}

Penduduk Dusun Aruk berjumlah 233 orang/jiwa yang terbagi menjadi 126 jiwa laki-laki dan 107 jiwa perempuan. Penduduk Dusun Aruk datang dari berbagai etnis yaitu etnis Melayu, Tionghoa, Bugis, dan yang paling dominan adalah etnis Dayak. Penduduk Dusun Aruk juga menganut beberapa jenis agama antara lain agama islam, Kristen protestan dan yang paling dominan adalah agama katolik. Rata-rata penduduk Dusun Aruk sudah menikah dan memiliki pekerjaan seperti PNS, pedagang, guru honor, aparatur desa, pegawai kontrak, pelajar dan yang paling dominan adalah petani dan tukang kebun. Persebaran permukiman penduduk Dusun Aruk dapat kategori menjadi tiga yaitu permukiman kampung yang tersebar di Jalan Kampung sekaligus menjadi kampung pertama, permukinan perintis yang tersebar di Jalan Perintis dan permukiman di Jalan Border yang merupakan permukiman masyarakat pendatang dan bukan domisili Dusun Aruk. Tempat tinggal penduduk rata-rata merupakan milik pribadi dan permanen namun ada juga yang milik pemerintah.

Lingkungan Dusun Aruk dipenuhi oleh sektor perkebunan dan pertanian. Sektor perkebunan berupa kebun karet, tanaman lada, dan kebun sawit. Sektor pertanian berupa sawah dan sebagian kecil sayursayuran atau buah-buahan seperti jagung, pisang, singkong dan sejenisnya. Sektor perkebunan dan pertanian tersebut merupakan hak milik pribadi atau milik masing-masing masyarakat Dusun Aruk. Hasil dari sektor tersebut disimpan ditempat tinggal masing-masing karena tidak terdapat tempat penyimpanan 
secara khusus baik komunal ataupun komunitas. Sumber air bersih di Dusun Aruk bersumber dari mata air gunung yang di alirkan dengan menggunakan pipa hingga ke unit rumah. Namun, sistem pemipaan air gunung ini tidak merata diakibatkan oleh aliran air gunung yang tidak teratur. Kondisi iklim lingkungan Dusun Aruk memiliki temperatur rata-rata berkisar 33,3 oC dan kelembaban rata-rata sekitar 65,65\%.

Dusun Aruk memiliki dua jalur transportasi utama yaitu jalan baru atau Jalan Perintis dan Jalan Kampung. Jalan Perintis berbahan beton yang menghubungkan antara jalan merdeka dari desa kaliau' dan Jalan Kampung. Jalan Kampung berbahan aspal. Transportasi public yang melalui jalan Merdeka dan Jalan Border di golongkan berdasarkan macam dan jenis moda transportasinya meliputi bus, mobil travel, bus Damri, dan ojek motor. Umumnya, jalan Merdeka dan Jalan Border merupakan jalan satu arah atau bisa digolongkan sebagai jalan kelas kolektor. Infrastruktur lainnya yang tersedia ialah saluran drainase yang masih belum merata. Selain itu, terdapat pula infrastruktur sarana komunikasi, sosial dan ekonomi, dua Pos TNI, kantor CU, kantor JNE, pasar berlampar (pasar non permanen) dan kantor posDusun Aruk memiliki beberapa fasilitas umum diantaranya yaitu SMPN, SDN, PAUD, Mess Desa, Kantor Desa, Gedung Serbaguna, Puskesdes, Posyandu, Pustu, Pasar, Pos Siskambling, Dua Gereja Kristen, Gereja Katolik Dan Mushola. Fasilitas umum dusun Aruk tersebar di bagian ujung Jalan Perintis dan Jalan Kampung. Fasilitas Pendidikan SD memiliki tenaga pengajar ASN lima orang dan honor dua orang, sedangkan tenaga pengajar SMP total 13 orang. Fasilitas kesehatan memiliki satu orang perawat bertugas di pustu dan satu orang bidan bertugas di puskesdes.

\section{Kesiapan Menuju Desa Cerdas Desa Perbatasan (Dusun Aruk)}

Dalam perhitungan pilar desa cerdas, terdapat setidaknya empat pilar yang dapat di eksplorasi terkait dengan kesesuaiannya. 4 pillar tersebut diantaranya adalah mengenai infrastruktur fisik, isu sosial, lingkungan, dan pemerintahan. Desa cerdas erat hubungannya dengan penggunaan teknologi dan media, dimana salah satu unsut terpenting yang perlu ada yaitu keberadaan jaringan internet dan penggunanaannya (Ahlawat, 2017; Shukla, 2016). Untuk mengukur pilar desa cerdas, perlu diukur terlebih dahulu literasi atau kesiapan ICT pada masyarakat sehingga diketahui seberapa siap masyarakat desa dalam penerapan konsep desa cerdas. Beberapa indikator dikembangkan beerdasarkan beberapa pustaka, diantaranya (Burhan, 2015; Covello, 2010; Johnson, 2007; Catts el al, 2008; Wahyono et al, 2010). Dari temuan yang dihasilkan dan justifikasi yang dilakukan, indikasi penilaian Literasi/Melek ICT masyarakat desa perbatasan dapat dideskripsikan sebagai berikut:

Tabel 1. Indikasi Penilaian Literasi/Melek ICT Masyarakat Desa

\begin{tabular}{|c|c|c|c|c|}
\hline No & Indikator & Klasifikasi dan Bobot & Skor & Justifikasi Hasil \\
\hline 1 & $\begin{array}{l}\text { Persentase Rumah } \\
\text { Tangga menguasai PC/ } \\
\text { Laptop }\end{array}$ & $\begin{array}{l}\text { - } \text { Diatas/ sama dengan 80\% (3) } \\
\text { - Antara 50\%- 80\% (2) } \\
\text { - } \text { Dibawah/sama dengan 50\% } \\
\text { (1) }\end{array}$ & 1 & $\begin{array}{l}\text { Memiliki komputer }=13 \% \text {, tidak ada }= \\
87 \%\end{array}$ \\
\hline 2 & $\begin{array}{l}\text { Persentase Rumah } \\
\text { Tangga dengan akses } \\
\text { internet }\end{array}$ & $\begin{array}{l}\text { - Diatas/ sama dengan 80\% (3) } \\
\text { - Antara 50\%- 80\% (2) } \\
\text { - Dibawah/sama dengan 50\% } \\
\text { (1) }\end{array}$ & 1 & $\begin{array}{l}\text { Sering akses internet }=27 \% \text {, tidak } \\
\text { sering } 15 \% \text {, dan tidak pernah } 59 \%\end{array}$ \\
\hline 3 & $\begin{array}{l}\text { Persentase Penduduk } \\
\text { mendengarkan siaran TV }\end{array}$ & $\begin{array}{l}\text { - Diatas/ sama dengan 80\% (3) } \\
\text { - Antara 50\%- 80\% (2) } \\
\text { - Dibawah/sama dengan 50\% } \\
\text { (1) }\end{array}$ & 3 & $\begin{array}{l}\text { Sering mendengar siaran TV }=92 \% \text {, } \\
\text { jarang menggunakan }=5 \% \text {, dan tidak } \\
\text { ada TV }=4 \%\end{array}$ \\
\hline 4 & $\begin{array}{l}\text { Persentase Penduduk } \\
\text { mendengarkan siaran } \\
\text { radio }\end{array}$ & $\begin{array}{l}\text { - Diatas/ sama dengan 80\% (3) } \\
\text { - Antara 50\% - 80\% (2) } \\
\text { - Dibawah/sama dengan 50\% } \\
\text { (1) }\end{array}$ & 1 & $\begin{array}{l}\text { Sering mendengar siaran radio }=0 \% \text {, } \\
\text { jarang menggunakan }=1 \% \text {, dan tidak } \\
\text { ada radio }=99 \%\end{array}$ \\
\hline
\end{tabular}




\begin{tabular}{|c|c|c|c|c|}
\hline No & Indikator & Klasifikasi dan Bobot & Skor & Justifikasi Hasil \\
\hline 5 & $\begin{array}{l}\text { Persentase Penduduk } \\
\text { membaca surat kabar }\end{array}$ & $\begin{array}{l}\text { - Diatas/ sama dengan } 80 \%(3) \\
\text { - Antara } 50 \%-80 \%(2) \\
\text { - Dibawah/sama dengan 50\% } \\
\text { (1) }\end{array}$ & 1 & $\begin{array}{l}\text { berlangganan surat kabar }=1 \% \text {, tidak } \\
\text { berlangganan, tapi membaca }=2 \% \text {, } \\
\text { dan tidak berlangganan }=97 \%\end{array}$ \\
\hline 6 & $\begin{array}{l}\text { Persentase Rumah } \\
\text { Tangga memiliki telepon } \\
\text { rumah }\end{array}$ & $\begin{array}{l}\text { - Diatas/ sama dengan } 80 \%(3) \\
\text { - Antara } 50 \%-80 \%(2) \\
\text { - Dibawah/sama dengan } 50 \% \\
\text { (1) } \\
\text { - Diatas/ sama dengan } 80 \%(3)\end{array}$ & 1 & Ada $=0 \%$, tidak ada $=100 \%$ \\
\hline 7 & $\begin{array}{l}\text { Persentase Rumah } \\
\text { Tangga menguasai HP }\end{array}$ & $\begin{array}{l}\text { - Antara } 50 \%-80 \%(2) \\
\text { - Dibawah/sama dengan } 50 \% \\
\text { (1) } \\
\text { - Diatas/ sama dengan } 80 \%(3)\end{array}$ & 2 & $\begin{array}{l}\text { Menggunakan HP }=74 \% \text {, tidak ada HP } \\
26 \%\end{array}$ \\
\hline 8 & $\begin{array}{l}\text { Persentase Kepemilikan } \\
\text { buku }\end{array}$ & $\begin{array}{l}\text { - Antara } 50 \%-80 \%(2) \\
\text { - Dibawah/sama dengan } 50 \% \\
\text { (1) } \\
\text { - Diatas/ sama dengan } 80 \% \text { (3) }\end{array}$ & 1 & $\begin{array}{l}\text { Memiliki buku }=3 \% \text {, tidak memiliki } \\
\text { buku }=97 \%\end{array}$ \\
\hline 9 & $\begin{array}{l}\text { Persentase keberadaan } \\
\text { Aplikasi HP }\end{array}$ & $\begin{array}{l}\text { - Antara } 50 \%-80 \%(2) \\
\text { - Dibawah/sama dengan } 50 \% \\
\text { (1) } \\
\text { - Diatas/ sama dengan } 80 \% \text { (3) }\end{array}$ & 2 & $\begin{array}{l}\text { HP dengan aplikasi 51\%, tidak ada } \\
\text { aplikasi } 49 \%\end{array}$ \\
\hline 10 & $\begin{array}{l}\text { Persentase Penggunaan } \\
\text { komputer dan internet }\end{array}$ & $\begin{array}{l}\text { - Antara } 50 \%-80 \%(2) \\
\text { - Dibawah/sama dengan } 50 \% \\
\text { (1) }\end{array}$ & 1 & $\begin{array}{l}\text { Bisa menggunakan internet }=27 \% \text {, } \\
\text { Tidak sering }=15 \% \text {, tidak pernah } 59 \%\end{array}$ \\
\hline 11 & $\begin{array}{l}\text { Persentase pengetahuan } \\
\text { Konsekuensi dan dampak } \\
\text { penggunaan ICT pada } \\
\text { perangkat desa }\end{array}$ & $\begin{array}{l}\text { - Diatas/ sama dengan } 80 \% \text { (3) } \\
\text { - Antara 50\%-80\% (2) } \\
\text { - Dibawah/sama dengan 50\% } \\
\text { (1) }\end{array}$ & 2 & $\begin{array}{l}\text { Mengetahui dampak ICT }=74 \% \text {, belum } \\
\text { mengetahui }=26 \%\end{array}$ \\
\hline & Total Skor & & 16 & \\
\hline
\end{tabular}

Sumber: Data Penelitian, 2019

Untuk hasil penilaian, total bobot nilai tertinggi adalah nilai 3 dikali jumlah pembobotan yaitu $3 \times 11=$ 33. Sedangkan total bobot nilai terendah adalah nilai 1 dikali jumlah pembobotan yaitu $1 \times 11=11$. Apabila rentang penilaian dibagi tiga kategori (Tinggi, Sedang, dan Rendah), maka nilai daya saing dusun dapat di klasifikasikan sebagai berikut:

1. $25.1-33=$ Tinggi

2. $18.1-25=$ Sedang

3. $11-18=$ Rendah

Dilihat dari total nilai pembobotan indicator dihasilkan nilai daya saing adalah 16 , yang apabila di sesuaikan dengan klasifikasi maka Literasi ICT masyarakat dusun Aruk masuk dalam kategori RENDAH.

Setelah mengetahui kondisi atau batas ambang literasi atau kesiapan ICT masyarakat desa, selanjutnya pengukuran lengkap terhadap kesiapan desa menuju desa cerdas dilakukan. Dari adaptasi beberapa pustaka (Somwanshi et al, 2016; Fannel et al, 2018; PWC, 2017; Ramachandra et al, 2015; Shukla, P Y. 2016), didapati secara umum bahwa terdapat 4 pilar desa cerdas yang kemudian di klasifikasikan lebih detil dalam 7 kategori pengukuran yang terdiri atas: (1) fisik, (2) energi, (3) sanitasi dan drainase, (4) sosial ekonomi, (5) lingkungan, (6) masyarakat dan pemerintahan, serta (7) kompetensi ICT perangkat desa. Dari pengukuran yang dilakukan didapati hasil sebagai berikut: 
Muazir, Lestari, Alhamdani, Nurhamsyah / Jurnal Pembangunan Wilayah dan Kota, Vol. 16, No. 2, 120-135

Doi: https://doi.org/10.14710/pwk.v16i2.27417

Tabel 2. Indikasi Pengukuran Bobot Pilar Desa Cerdas

\begin{tabular}{|c|c|c|c|c|}
\hline No & Indikator & Klasifikasi dan Bobot & Skor & Justifikasi Hasil \\
\hline & \multicolumn{4}{|l|}{ Fisik } \\
\hline 1 & $\begin{array}{l}\text { Keberadaan jalan yang } \\
\text { menghubungkan ke Desa } \\
\text { lainnya atau Pusat Kota }\end{array}$ & $\begin{array}{l}\text { - Ada dan baik (3) } \\
\text { - Ada tapi kurang baik (2) } \\
\text { - Ada tapi buruk (1) }\end{array}$ & 2 & $\begin{array}{l}\text { Terdapat jalan perintis dan jalan } \\
\text { kampung yang masih baik dan } \\
\text { terhubung ke jl. Merdeka dan } \\
\text { jalan lainnya }\end{array}$ \\
\hline 2 & $\begin{array}{l}\text { Macam dan jenis sarana } \\
\text { transportasi masyarakat }\end{array}$ & $\begin{array}{l}\text { - Dominan menggunakan } \\
\text { angkutan umum (3) } \\
\text { - Dominan menggunakan mobil/ } \\
\text { sepeda motor (2) } \\
\text { - Dominan menggunakan sepeda } \\
\text { (1) }\end{array}$ & 2 & $\begin{array}{l}\text { Mayoritas menggunakan } \\
\text { kendaraan roda } 2 \text { dan sedikit } \\
\text { yang menggunakan mobil }\end{array}$ \\
\hline 3 & $\begin{array}{l}\text { Macam dan jenis moda } \\
\text { transportasi (publik) yang } \\
\text { ada }\end{array}$ & $\begin{array}{l}\text { - Minimal ada bis (3) } \\
\text { - Minimal ada mobil travel (2) } \\
\text { - Minimal ada motor (1) }\end{array}$ & 3 & $\begin{array}{l}\text { Terdapat transportasi bis } \\
\text { Damri, bis kecil, mobil taksi } \\
\text { lokal (travel), dan ojek motor. }\end{array}$ \\
\hline 4 & $\begin{array}{l}\text { Kemudahan konektivitas ke } \\
\text { wilayah lain serta macam } \\
\text { moda transportasi yang ada } \\
\text { (adanya transportasi publik } \\
\text { dan jalan yang } \\
\text { menghubungkan antar } \\
\text { Desa/wilayah) }\end{array}$ & $\begin{array}{l}\text { - Ada dan baik dan minimal ada bis } \\
\text { ( } 3 \text { ) } \\
\text { - Ada tapi kurang baik dan } \\
\text { minimal ada bis ( } 2 \text { ) } \\
\text { - Ada tapi buruk dan minimal ada } \\
\text { ojek motor (1) }\end{array}$ & 2 & $\begin{array}{l}\text { Kewilayah tertentu dapat } \\
\text { dengan transportasi bis Damri, } \\
\text { bis kecil, mobil taksi lokal } \\
\text { (travel), dan ojek motor. Untuk } \\
\text { wilayah lebih mendalam hanya } \\
\text { dapat menggunakan motor } \\
\text { atau sejenisnya }\end{array}$ \\
\hline \multirow[t]{2}{*}{5} & $\begin{array}{l}\text { Keberadaan dan kapasitas } \\
\text { kabel telekomunikasi atau } \\
\text { sinyal telekomunikasi, } \\
\text { provider telekomunikasi }\end{array}$ & $\begin{array}{l}\text { - Ada dan kuat (3) } \\
\text { - Ada tapi lemah (2) } \\
\text { - Tidak ada (1) }\end{array}$ & 3 & $\begin{array}{l}\text { Terdapat } 2 \text { tower milik } \\
\text { telkomsel dan } 1 \text { tower milik XL }\end{array}$ \\
\hline & Energi & & & \\
\hline 6 & $\begin{array}{l}\text { Energi dominan yang } \\
\text { digunakan masyarakat Desa }\end{array}$ & $\begin{array}{l}\text { - listrik dari PLN (3) } \\
\text { - lampu minyak (2) } \\
\text { - tidak ada (1) }\end{array}$ & 3 & $\begin{array}{l}\text { Semua menggunakan listrik } \\
(100 \%)\end{array}$ \\
\hline 7 & $\begin{array}{l}\text { Iklim setempat (lama/ jam } \\
\text { sinaran matahari perhari) }\end{array}$ & $\begin{array}{l}\text { - Diatas/ sama dengan } 5 \text { jam (3) } \\
\text { - Diantara } 4 \text { - } 5 \text { jam (2) } \\
\text { - Dibawah/ sama dengan } 4 \text { jam (1) }\end{array}$ & 3 & $\begin{array}{l}\text { Lama penyinaran matahari di } \\
\text { daerah sekitar Sambas kurang } \\
\text { lebih } 5-6 \text { jam }\end{array}$ \\
\hline 8 & $\begin{array}{l}\text { Keberadaan/ potensi air } \\
\text { terjun untuk pembangkit } \\
\text { listrik }\end{array}$ & $\begin{array}{l}\text { - Ada dan besar (3) } \\
\text { - Ada tapi kecil (2) } \\
\text { - Tidak ada (1) }\end{array}$ & 1 & $\begin{array}{l}\text { Tidak ada potensi pembangkit } \\
\text { listrik dari air terjun }\end{array}$ \\
\hline 9 & $\begin{array}{l}\text { Keberadaan/ potensi limbah } \\
\text { industri kayu, limbah } \\
\text { pertanian (kotoran hewan } \\
\text { ternak, ampas pertanian), }\end{array}$ & $\begin{array}{l}\text { - Ada dan dimanfaatkan (3) } \\
\text { - Ada dan hanya sedikit } \\
\text { dimanfaatkan (2) } \\
\text { - Tidak ada/ belum dimanfaatkan } \\
\text { (1) }\end{array}$ & 1 & $\begin{array}{l}\text { Terdapat kotoran hewan dan } \\
\text { limbah pertanian namun tidak } \\
\text { dikelola masyarakat }\end{array}$ \\
\hline & Sanitasi dan drainase & & & \\
\hline 10 & $\begin{array}{l}\text { Panjang jalan yang telah } \\
\text { terdapat drainase }\end{array}$ & $\begin{array}{l}\text { - Semua jalan ada (3) } \\
\text { - Hanya sebagian jalan (2) } \\
\text { - Tidak ada (1) }\end{array}$ & 2 & $\begin{array}{l}\text { Drainase hanya ada pada jl. } \\
\text { Kampung dan jl. Merdeka, }\end{array}$ \\
\hline 11 & $\begin{array}{l}\text { Jumlah Rumah Tangga yang } \\
\text { telah memiliki septiktank }\end{array}$ & $\begin{array}{l}\text { - Diatas/ sama dengan 80\% (3) } \\
\text { - Antara 50\% - 80\% (2) } \\
\text { - Dibawah/sama dengan 50\% (1) }\end{array}$ & 3 & $\begin{array}{l}\text { Rumah memiliki septiktank }= \\
99 \% \text {, tidak ada }=1 \%\end{array}$ \\
\hline 12 & $\begin{array}{l}\text { Jumlah Rumah Tangga yang } \\
\text { telah memiliki sumber air } \\
\text { bersih pipa (PDAM) }\end{array}$ & $\begin{array}{l}\text { - Diatas/ sama dengan 80\% (3) } \\
\text { - Antara 50\%- 80\% (2) } \\
\text { - Dibawah/sama dengan 50\% (1) }\end{array}$ & 1 & $\begin{array}{l}\text { Penggunaan sumber air bersih } \\
\text { PDAM }=21 \%\end{array}$ \\
\hline
\end{tabular}


Muazir, Lestari, Alhamdani, Nurhamsyah / Jurnal Pembangunan Wilayah dan Kota, Vol. 16, No. 2, 120-135

Doi: https://doi.org/10.14710/pwk.v16i2.27417

\begin{tabular}{|c|c|c|c|c|}
\hline No & Indikator & Klasifikasi dan Bobot & Skor & Justifikasi Hasil \\
\hline 13 & $\begin{array}{l}\text { Jumlah Rumah Tangga yang } \\
\text { membuang air kotor ke } \\
\text { jaringan drainase }\end{array}$ & $\begin{array}{l}\text { - Diatas/ sama dengan 80\% (3) } \\
\text { - Antara } 50 \% \text { - 80\% (2) } \\
\text { - Dibawah/sama dengan } 50 \%(1)\end{array}$ & 1 & $\begin{array}{l}\text { Pembuangan ke saluran } \\
\text { drainase }=91 \% \text {, sungai } 2 \% \text {, parit } \\
1 \% \text {, selokan Alami } 5 \% \text {, WC umum } \\
1 \%\end{array}$ \\
\hline & \multicolumn{4}{|l|}{ Sosial dan Ekonomi } \\
\hline 14 & $\begin{array}{l}\text { Jumlah dan lokasi fasilitas- } \\
\text { fasilitas kesehatan }\end{array}$ & $\begin{array}{l}\text { - Ada lebih dari } 1 \text { dan dekat } \\
\text { dengan permukiman ( } 3 \text { ) } \\
\text { - Ada } 1 \text { dan dekat dengan } \\
\text { permukiman (2) } \\
\text { - Ada } 1 \text { dan jauh dari permukiman } \\
\text { (1) }\end{array}$ & 3 & $\begin{array}{l}\text { Terdapat puskesdes dan pustu } \\
\text { (puskesmas pembantu) yang } \\
\text { memiliki jarak terjauh } 2.67 \mathrm{~km}\end{array}$ \\
\hline 15 & $\begin{array}{l}\text { Jumlah dan lokasi fasilitas- } \\
\text { fasilitas keamanan Desa (pos } \\
\text { Polisi, siskamling, pos TNI, } \\
\text { dlI) }\end{array}$ & $\begin{array}{l}\text { - Ada Ada lebih dari } 1 \text { pos } \\
\text { keamanan (3) } \\
\text { - Ada } 1 \text { pos keamanan (2) } \\
\text { - Tidak ada pos keamanan (1) }\end{array}$ & 3 & $\begin{array}{l}\text { Terdapat } 2 \text { pos penjagaan } \\
\text { militer dan } 1 \text { pos kamling }\end{array}$ \\
\hline 16 & $\begin{array}{l}\text { Jumlah dan lokasi fasilitas- } \\
\text { fasilitas pendidikan (SD, SMP, } \\
\text { SMU) }\end{array}$ & $\begin{array}{l}\text { - Ada SD, SMP, SMU dan jarak } \\
\text { terjauh kurang dari } 3 \mathrm{~km} \text { (3) } \\
\text { - Ada SD, SMP dan jarak terjauh } \\
\text { kurang dari } 3 \mathrm{~km}(2) \\
\text { - Ada SD dan jarak terjauh kurang } \\
\text { dari } 3 \mathrm{~km} \text { (1) }\end{array}$ & 2 & $\begin{array}{l}\text { Terdapat } 1 \text { SD N dan } 1 \text { SMP N } \\
\text { dan jarak terjauh } 2.77 \mathrm{~km}\end{array}$ \\
\hline 17 & $\begin{array}{l}\text { Keberadaan dan frekuensi } \\
\text { pelatihan-pelatihan } \\
\text { sosial/ekonomi (wirausaha, } \\
\text { pengolahan hasil-hasil } \\
\text { pertanian dan peternakan) }\end{array}$ & $\begin{array}{l}\text { - Ada dan sering (3) } \\
\text { - Ada tapi jarang (2) } \\
\text { - Tidak ada (1) }\end{array}$ & 3 & $\begin{array}{l}\text { Pelatihan wirausaha sering } \\
\text { dilakukan di Gedung serbaguna }\end{array}$ \\
\hline 18 & $\begin{array}{l}\text { Jumlah dan lokasi sekolah } \\
\text { (SD, SMP, SMU) yang } \\
\text { memiliki akses internet untuk } \\
\text { fasilitas pembelajaran }\end{array}$ & $\begin{array}{l}\text { - Ada dan lancar (3) } \\
\text { - Ada tapi tidak lancar (2) } \\
\text { - Tidak ada (1) }\end{array}$ & 1 & $\begin{array}{l}\text { Fasilitas Pendidikan tidak ada } \\
\text { akses internet }\end{array}$ \\
\hline 19 & $\begin{array}{l}\text { Jumlah dan lokasi puskesmas } \\
\text { yang memiliki akses internet } \\
\text { untuk fasilitas administrasi }\end{array}$ & $\begin{array}{l}\text { - Ada dan lancar (3) } \\
\text { - Ada tapi tidak lancar (2) } \\
\text { - Tidak ada (1) }\end{array}$ & 1 & $\begin{array}{l}\text { Fasilitas kesehatan tidak ada } \\
\text { akses internet }\end{array}$ \\
\hline 20 & $\begin{array}{l}\text { Standar pelayanan medis } \\
\text { terhadap masyarakat dan } \\
\text { pola-pola penggunaan } \\
\text { layanan kesehatan dari } \\
\text { masyarakat }\end{array}$ & $\begin{array}{l}\text { - Ada yang khusus lingkup dusun, } \\
24 \text { jam dan bisa on call ( } 3 \text { ) } \\
\text { - Ada yang khusus lingkup desa, } \\
\text { dan tidak bisa on call ( } 2 \text { ) } \\
\text { - Ada yang khusus lingkup desa, } \\
\text { tapi tidak ada layanan khusus (1) }\end{array}$ & 3 & $\begin{array}{l}\text { Layanan Pustu: membantu } \\
\text { puskesmas khusus desa } \\
\text { sebunga } \\
\text { Layanan puskesdes: } \\
\text { Khusus desa sebunga, } \\
\text { pelayanan } 24 \text { jam, bisa melayani } \\
\text { on call. }\end{array}$ \\
\hline 21 & $\begin{array}{l}\text { Jumlah/persentase } \\
\text { penggunaan hasil } \\
\text { pertanian/peternakan untuk } \\
\text { dikonsumsi sendiri }\end{array}$ & $\begin{array}{l}\text { - Dibawah/sama dengan 50\% (3) } \\
\text { - Diantara 50\% - 80\% (2) } \\
\text { - Diatas/ sama dengan } 80 \% \text { (1) }\end{array}$ & 3 & $\begin{array}{l}\text { Hasil pertanian yang dikonsumsi } \\
\text { diatas } 50 \%=16 \% \text {, dibawah } 50 \%= \\
84 \%\end{array}$ \\
\hline 22 & $\begin{array}{l}\text { Asal wilayah/ daerah } \\
\text { pemasok sembako (yang } \\
\text { berasal dari wilayah lain) }\end{array}$ & $\begin{array}{l}\text { - Ada dan banyak (3) } \\
\text { - Ada namun tidak banyak (2) } \\
\text { - Tidak ada (1) }\end{array}$ & 2 & $\begin{array}{l}\text { Didapat dari daerah Malaysia } \\
\text { (daerah lundu dan biawak) }\end{array}$ \\
\hline 23 & $\begin{array}{l}\text { Keberadaan dan lokasi } \\
\text { gudang atau tempat } \\
\text { penyimpanan hasil-hasil } \\
\text { pertanian dan barang }\end{array}$ & $\begin{array}{l}\text { - Ada dan dipakai komunal (3) } \\
\text { - Ada di tempat tinggal masing- } \\
\text { masing (2) } \\
\text { - Tidak ada (1) }\end{array}$ & 2 & $\begin{array}{l}\text { Menyimpanan hasil pertanian di } \\
\text { tempat tinggal masing-masing }\end{array}$ \\
\hline
\end{tabular}




\begin{tabular}{llll}
\hline No & Indikator & Klasifikasi dan Bobot & Skor
\end{tabular}

\begin{tabular}{|c|c|c|c|c|}
\hline 24 & $\begin{array}{l}\text { Macam binatang ternak yang } \\
\text { diusahakan serta kondisi } \\
\text { penangkaran }\end{array}$ & $\begin{array}{l}\text { - Ada lebih dari } 4 \text { binatang dengan } \\
\text { penangkaran baik (3) } \\
\text { - Ada lebih dari } 4 \text { binatang dengan } \\
\text { penangkaran tidak baik (2) } \\
\text { - Ada kurang dari } 4 \text { binatang dan } \\
\text { penangkaran tidak baik (1) }\end{array}$ & 3 & $\begin{array}{l}\text { Jenis ternak yaitu ayam } 40 \% \text {, } \\
\text { babi } 49 \% \text {, sapi } 2 \% \text {, bebek } 2 \% \text {, } \\
\text { kambing } 2 \% \text {, ikan } 4 \%\end{array}$ \\
\hline \multirow[t]{2}{*}{25} & $\begin{array}{l}\text { Banyak usaha/bisnis yang } \\
\text { ada, dan jenis usaha yang di } \\
\text { jalankan }\end{array}$ & $\begin{array}{l}\text { - Ada beberapa dan diluar sektor } \\
\text { pertanian (3) } \\
\text { - Ada di satu sektor (2) } \\
\text { - Tidak ada (1) }\end{array}$ & 2 & $\begin{array}{l}\text { Dominan berusaha di sektor } \\
\text { pertanian }=55 \%\end{array}$ \\
\hline & \multicolumn{4}{|l|}{ Lingkungan } \\
\hline 26 & $\begin{array}{l}\text { Banyak kadar } \mathrm{CO}_{2} \\
\text { (pengukuran) }\end{array}$ & $\begin{array}{l}\text { - Kurang dari } 400 \text { ppm (3) } \\
\text { - Antara } 400-1000 \text { ppm (2) } \\
\text { - Lebih dari } 1000 \text { ppm (1) }\end{array}$ & 3 & $\begin{array}{l}\text { o sampai dibawah } 400 \text { ppm } \\
\text { (diruang terbuka) }\end{array}$ \\
\hline 27 & $\begin{array}{l}\text { Keikutsertaan (keaktifan) } \\
\text { Pemerintah Desa dalam } \\
\text { musrembang dalam } \\
\text { merencanakan } \\
\text { pembangunan Desa }\end{array}$ & $\begin{array}{l}\text { - Ada dan aktif (3) } \\
\text { - Ada tapi kurang aktif (2) } \\
\text { - Tidak ada (1) }\end{array}$ & 3 & $\begin{array}{l}\text { Terdapat pertemuan rutin } \\
\text { secara formal yang biasa di } \\
\text { laksanakan di gedung } \\
\text { sebaguna. }\end{array}$ \\
\hline 28 & $\begin{array}{l}\text { Keberadaan rencana } \\
\text { pengembangan Desa }\end{array}$ & $\begin{array}{l}\text { - Ada dan direncanakan (3) } \\
\text { - Ada namun belum direncanakan } \\
\text { ( } 2 \text { ) } \\
\text { - Tidak ada (1) }\end{array}$ & 3 & $\begin{array}{l}\text { Dusun aruk direncanakan untuk } \\
\text { dipecah menjadi dua dusun }\end{array}$ \\
\hline 29 & $\begin{array}{l}\text { Jenis tanaman dan luas jenis } \\
\text { pertanian di Desa } \\
\text { (perkebunan, sawah, ladang } \\
\text { berpindah) }\end{array}$ & $\begin{array}{l}\text { - Lebih dari } 5 \text { jenis tanaman (lada, } \\
\text { karet, sawah, sawit, singkong, } \\
\text { dst)(3) } \\
\text { - Kurang dari } 5 \text { jenis tanaman (2) } \\
\text { - Tidak ada (1) }\end{array}$ & 3 & $\begin{array}{l}\text { Terdapat tanaman lada, karet, } \\
\text { sawah, sedikit tanaman sawit, } \\
\text { jagung, pisang, singkong, dan } \\
\text { sejenisnya. }\end{array}$ \\
\hline 30 & $\begin{array}{l}\text { Bencana (gempa, longsor, } \\
\text { banjir) yang pernah terjadi } \\
\text { dan penanggulangannya }\end{array}$ & $\begin{array}{l}\text { - Tidak pernah terjadi bencana (3) } \\
\text { - Bencana cuma banjir dan tidak } \\
\text { ada penanggulangan (2) } \\
\text { - Terdapat bencana gempa, } \\
\text { longsor, banjir dan tidak ada } \\
\text { penangulangan (1) }\end{array}$ & 2 & $\begin{array}{l}\text { Sering banjir untuk daerah jalan } \\
\text { perintis dan tidak ada tindak } \\
\text { penanggulangan }\end{array}$ \\
\hline & & - Tidak ada (3) & & \\
\hline 31 & Keberadaan limbah industri & $\begin{array}{l}\text { - Ada tapi sedikit (2) } \\
\text { - Ada dan banyak (1) }\end{array}$ & 3 & Tidak ada limbah industri \\
\hline 32 & $\begin{array}{l}\text { Keberadaan pengusahaan } \\
\text { pertanian organik }\end{array}$ & $\begin{array}{l}\text { - Ada beberapa (3) } \\
\text { - Ada minimal } 1 \text { (2) } \\
\text { - Tidak ada (1) }\end{array}$ & 1 & $\begin{array}{l}\text { Tidak ada pengusaha pertanian } \\
\text { organik }\end{array}$ \\
\hline 33 & $\begin{array}{l}\text { Keberadaan sumber air } \\
\text { bersih alam (sumur, sungai, } \\
\text { hujan) }\end{array}$ & $\begin{array}{l}\text { - Ada beberapa pilihan (3) } \\
\text { - Ada dari satu sumber (air } \\
\text { pegunungan) (2) } \\
\text { - Tidak ada (1) }\end{array}$ & 2 & $\begin{array}{l}\text { Menggunakan sistem pipanisasi } \\
\text { dari sumber mata air } \\
\text { pegunungan }\end{array}$ \\
\hline
\end{tabular}

\section{Masyarakat dan Pemerintahan}

- Ada dan sering (3)

- Ada tapi jarang (2)

- Tidak ada (1)
Terdapat pertemuan rutin secara formal yang biasa di Gedung sebaguna. Melaksanakan kegiatan keagamaan seminggu sekali, acara adat seperti sunatan, adat 


$\begin{array}{llll}\text { No Indikator } & \text { Klasifikasi dan Bobot } & \text { Skor } & \text { Justifikasi Hasil }\end{array}$

laporan kependudukan/ kepemerintahan yang baik dan lengkap

Prosedur dan standar pelaporan vertikal

36 administrasi kepemerintahan (misal Kepala Desa ke Camat, dst)

Keberadaan, jumlah, spesifikasi, dan sistem operasi komputer yang ada di kantor pemerintahan Keberadaan, jumlah dan spesifikasi alat pendukung

38 komputer (scanner, printer, modem, ruter wifi) yang ada di kantor pemerintahan

Jumlah dan lokasi kantor pemerintahan yang memiliki akses internet untuk fasilitas administrasi

Cara penyampaian informasi

40 (pemerintahan) ke masyarakat
- Ada dan sudah sesuai standar dari pemerintahan (3)

- Ada tapi belum sesuai standar dari pemerintahan (2)

- Tidak ada (1)

- Ada dan sudah menggunakan akses internet (otomatis) (3)

- Ada tapi belum menggunakan akses internet (2)

- Tidak ada (1)

- Terdapat beragam jenis (PC/Laptop) (3)

- Terdapat hanya satu jenis (2)

- Tidak ada (1)

- Terdapat beragam jenis pendukung (3)

- Terdapat hanya satu jenis (2)

- Tidak ada (1)

- Ada dan terdapat beberapa fasilitas akses internet (kabel/wifi) (3)

- Terdapat hanya satu jenis fasilitas (2)

- Tidak ada (1)

- Dengan berbagai media (internet, medsos, cetak) (3)

- Hanya menggunakan surat (2)

- Tidak ada (1)

tutop taon, menikah, gawai dll. Serta gotong royong Sistem pelaporan/rekap dilakukan manual dulu

3 kemudian diinput ke komputer sesuai dengan format standar dari pemerintah

Sistem pelaporan melalui via aplikasi input data yang sudah disediakan dengan menggunakan akses internet

Terdapat 6 unit komputer jinjing (laptop) dan 2 unit digunakan untuk operasional kantor desa

Kantor hanya terdapat printer scanner

Hanya menggunakan modem

2 atau internet hotspot handphone

Penyampaian resmi menggunakan media surat dan tidak resmi menggunakan telepon, via SMS, via WA.

\section{Kompetensi ICT Perangkat Desa}

- Sering menggunakan (3)

$41 \quad$ Akses internet

42 Kepemilikan komputer

43 Pencarian di website

Menggunakan layanan internet

45

Membuat dan mengelola blog

46
Mengubah tampilan komputer
- Tidak sering (2)

- Tidak pernah (1)

- Diatas/ sama dengan $80 \%$ (3)

- Antara 50\% - 80\% (2)

- Dibawah/sama dengan 50\% (1)

- Diatas/ sama dengan 80\% (3)

- Antara 50\%-80\% (2)

- Dibawah/sama dengan 50\% (1)

- Diatas/ sama dengan 80\% (3)

- Antara 50\% - 80\% (2)

- Dibawah/sama dengan 50\% (1)

- Diatas/ sama dengan 80\% (3)

- Antara 50\% - 80\% (2)

- Dibawah/sama dengan 50\% (1)

- Diatas/ sama dengan 80\% (3)

- Antara 50\% - 80\% (2)

- Dibawah/sama dengan 50\% (1)
Sering menggunakan internet =

$385 \%$, tidak sering $=15 \%$, tidak pernah $=0 \%$ ada $=33 \%$

Bisa melakukan pencarian di website $=83 \%$, tidak bisa $=17 \%$

Bisa menggunakan layanan internet $=83 \%$, tidak bisa $=17 \%$

Tidak bisa membuat dan mengelola blog

Dapat mengubah tampilan komputer $=71 \%$, tidak bisa $=29 \%$ 
Muazir, Lestari, Alhamdani, Nurhamsyah / Jurnal Pembangunan Wilayah dan Kota, Vol. 16, No. 2, 120-135

Doi: https://doi.org/10.14710/pwk.v16i2.27417

\begin{tabular}{|c|c|c|c|c|}
\hline No & Indikator & Klasifikasi dan Bobot & Skor & Justifikasi Hasil \\
\hline 47 & Pemanfaatan internet & $\begin{array}{l}\text { - Telah menggunakan dan sering } \\
\text { (3) } \\
\text { - Sudah menggunakan, namun } \\
\text { jarang (2) } \\
\text { - Belum menggunakan (1) }\end{array}$ & 3 & $\begin{array}{l}\text { Sering memanfaatkan internet } \\
=57 \% \text {, jarang menggunakan = } \\
43 \%\end{array}$ \\
\hline 48 & $\begin{array}{l}\text { Mengetahui dampak positif } \\
\text { internet }\end{array}$ & $\begin{array}{l}\text { - Diatas/ sama dengan 80\% (3) } \\
\text { - Antara } 50 \% \text { - 80\% (2) } \\
\text { - Dibawah/sama dengan 50\% (1) }\end{array}$ & 2 & $\begin{array}{l}\text { Telah mengetahui dampak } \\
\text { positif internet }=70 \% \text {, belum } \\
\text { mengetahui }=30 \%\end{array}$ \\
\hline 49 & $\begin{array}{l}\text { Mengetahui dampak negatif } \\
\text { internet }\end{array}$ & $\begin{array}{l}\text { - Diatas/ sama dengan 80\% (3) } \\
\text { - Antara } 50 \% \text { - 80\% (2) } \\
\text { - Dibawah/sama dengan 50\% (1) }\end{array}$ & 2 & $\begin{array}{l}\text { Telah mengetahui dampak } \\
\text { negatif internet }=74 \% \text {, belum } \\
\text { mengetahui }=26 \%\end{array}$ \\
\hline 50 & kepemilikan handphone (HP) & $\begin{array}{l}\text { - Diatas/ sama dengan 80\% (3) } \\
\text { - Antara } 50 \% \text { - 80\% (2) } \\
\text { - Dibawah/sama dengan } 50 \%(1)\end{array}$ & 3 & $\begin{array}{l}\text { Semua memiliki Handphone } \\
\text { (HP) }\end{array}$ \\
\hline 51 & $\begin{array}{l}\text { Kepemilikan aplikasi media } \\
\text { sosial di HP }\end{array}$ & $\begin{array}{l}\text { - Diatas/ sama dengan 80\% (3) } \\
\text { - Antara 50\% - 80\% (2) } \\
\text { - Dibawah/sama dengan 50\% (1) } \\
\text { - Akses internet (3) }\end{array}$ & 3 & $\begin{array}{l}\text { Semua memiliki aplikasi media } \\
\text { sosial }\end{array}$ \\
\hline 52 & Dominasi Penggunaan HP & $\begin{array}{l}\text { - Menelpon dan mengirim pesan } \\
\text { (2) } \\
\text { - Lainnya (game) (1) }\end{array}$ & 3 & $\begin{array}{l}\text { Menelepon }=48 \% \text {, mengirim } \\
\text { pesan }=4 \% \text {, dan internet }=48 \%\end{array}$ \\
\hline & Total Skor & & 126 & \\
\hline
\end{tabular}

Sumber: Data Penelitian, 2019

Untuk hasil penilaian, total bobot nilai tertinggi adalah nilai 3 dikali jumlah pembobotan yaitu $3 \times 53=$ 156. Sedangkan total bobot nilai terendah adalah nilai 1 dikali jumlah pembobotan yaitu $1 \times 53=53$. Apabila rentang penilaian dibai tiga kategori (Tinggi, Sedang, dan Rendah), maka nilai daya saing dusun dapat di klasifikasikan sebagai berikut:

1. $122,1-156=$ Tinggi

2. $87,1-122=$ Sedang

3. $52-87=$ Rendah

Dilihat dari total nilai pembobotan indikator dihasilkan nilai daya saing adalah 126, yang apabila di sesuaikan dengan klasifikasi maka pilar desa cerdas dusun Aruk masuk dalam kategori TINGGI. Namun, apabila dilihat dari masing-masing kategori dapat dilihat (tabel 3) bahwa secara umum, indikasi kekuatan yang dimiliki dan mendukung dusun aruk untuk menjadi desa cerdas terdapat pada kategori fisik/infrastruktur yang telah memadai, kondisi lingkungan yang cenderung masih alami, pendukung kegiatan pemerintahan yang cenderung memadai, dan perangkat desa yang telah siap dalam penggunaan ICT.

Dari beberapa temuan diatas, dapat dilihat bahwa secara umum pembangunan perbatasan telah dilakukan melalui pendekatan pembangungan fisik atau infrastruktur. Hal ini dapat dilhat dari rata-rata nilai kecenderungan dari fisik/infrastruktur dalam masing-masing tabel atau pengukuran. Apabila dilihat dari kesiapan masyarakat dalam mendukung penerapan teknologi komunikasi dalam hal indikasi dalam masingmasing aspek penilaian, secara umum masyarakat masih cenderung belum siap dengan melihat skor yang masih RENDAH. Dalam kesiapan ICT, secara umum masyarakat masih familiar dengan penggunaan televisi sebagai sumber informasi. Selain itu, penggunaan dan akses internet masih terbilang rendah, serta penggunaan handphone sebagai media komunikasi cenderung hanya digunakan untuk mendukung komunikasi dua arah (menelpon), cenderung belum memanfaatkan teknologi lainnya seperti internet. 
Muazir, Lestari, Alhamdani, Nurhamsyah / Jurnal Pembangunan Wilayah dan Kota, Vol. 16, No. 2, 120-135

Doi: https://doi.org/10.14710/pwk.v16i2.27417

Tabel 3. Penilaian Kategori Pilar Desa Cerdas

\begin{tabular}{|c|c|c|c|c|}
\hline No & Kategori & Total Skor & Range Penilaian & Hasil \\
\hline 1 & Fisik/infrastruktur & 12 & $\begin{array}{l}11.8-15=\text { Tinggi } \\
8.4-11.7=\text { Sedang } \\
5-8.3=\text { Rendah }\end{array}$ & TINGGI \\
\hline 2 & Energi & 8 & $\begin{array}{l}9.4-12=\text { Tinggi } \\
6.7-9.3=\text { Sedang } \\
4-6.6=\text { Rendah } \\
9.4-12=\text { Tinggi }\end{array}$ & SEDANG \\
\hline 3 & Drainase dan Sanitasi & 7 & $\begin{array}{l}6.7-9.3=\text { Sedang } \\
4-6.6=\text { Rendah }\end{array}$ & SEDANG \\
\hline 4 & Sosial Ekonomi & 28 & $\begin{array}{l}28.1-36=\text { Tinggi } \\
20.1-28=\text { Sedang } \\
12-20=\text { Rendah } \\
18.8-24=\text { Tingoi }\end{array}$ & SEDANG \\
\hline 5 & Lingkungan & 20 & $\begin{array}{l}13.4-18.7=\text { Sedang } \\
8-13.3=\text { Rendah }\end{array}$ & TINGGI \\
\hline 6 & $\begin{array}{l}\text { Masyarakat dan } \\
\text { Pemerintahan }\end{array}$ & 19 & $\begin{array}{l}16.4-21=\text { Tinggi } \\
11.7-16.3=\text { Sedang } \\
7-11.6=\text { Rendah }\end{array}$ & TINGGI \\
\hline 7 & $\begin{array}{l}\text { Kompetensi ICT Perangkat } \\
\text { Desa }\end{array}$ & 32 & $\begin{array}{l}28.1-36=\text { Tinggi } \\
20.1-28=\text { Sedang } \\
12-20=\text { Rendah }\end{array}$ & TINGGI \\
\hline
\end{tabular}

Sumber: Data Penelitian, 2019

Dari temuan pengukuran terhadap kesiapan menuju desa cerdas yang diukur melalui pilar desa cerdas didapati bahwa secara total kesiapan dusun aruk telah TINGGI. Apabila dilihat dalam masing-masing kategori penilaian (tabel 3), kondisi fisik/infrastruktur menjadi kategori penilaian yang tinggi (baik). Hal ini mengindikasikan bahwa pembangunan fisik di daerah perbatasan sejauh ini terus dilakukan dan menjadi perhatian. Selain kondisi fisik/infrastruktur, kategori penilaian yang masuk dalam kategori tinggi juga didapati dalam kategori penilaian (1) lingkungan, (2) masyarakat dan pemerintahan, serta (3) kompetensi ICT perangkat desa. Sedangkan penilaian dengan kategori sedang beberapa aspek penilaian masuk pada kategori energi, drainase dan sanitasi, serta sosial ekonomi.

Dari kondisi atau indikasi penilaian yang telah dilakukan, dapat dilihat bahwa kesiapan menjadi desa cerdas, desa/dusun di perbatasan telah memiliki potensi dalam pembangunan fisik dan infrastruktur yang ada. Hal ini juga perlu dilanjutkan dengan pembangunan non-fisik agar kualitas sumber daya (sosial dan ekonomi) juga meningkat secara kualitas. Dari perspektif pengembangan desa cerdas, kualitas literasi atau melek ICT masyarakat juga perlu menjadi perhatian serius, pembangunan fisik juga perlu memperhatikan bagaimana akselerasi masyarakat untuk mengikuti perkembangan teknologi, khususnya ICT yang telah menjadi bagian kehidupan sehari-hari untuk mendukung komunikasi dan pencarian informasi. Dari beberapa indikasi diatas, dapat dirangkum beberapa kekuatan, kelemahan, potensi serta kendala (SWOT) dalam mengembangakan konsep desa cerdas di dusuk Aruk.

Tabel 4. Analisis SWOT

\begin{tabular}{|c|c|c|c|c|}
\hline No & Kekuatan (S) & Kelemahan (W) & Potensi (0) & Kendala ( $\mathrm{T}$ ) \\
\hline & $\begin{array}{l}\text { - Konektivitas } \\
\text { transportasi maupun } \\
\text { telekomunikasi antar } \\
\text { wilayah sudah baik } \\
\text { - Sumber energi baik } \\
\text { - } \quad \text { Pekerjaan penduduk }\end{array}$ & $\begin{array}{l}\text { - Akses/jarak antar } \\
\text { desa/ dusun jauh } \\
\text { Kurangnya } \\
\text { pengetahuan dan } \\
\text { keterampilan atau } \\
\text { keinginan penduduk }\end{array}$ & $\begin{array}{l}\text { - Pengembangan } \\
\text { infrastruktur lanjut } \\
\text { dengan adanya } \\
\text { infrastruktur dasar } \\
\text { - } \text { Terdapat sumber } \\
\text { energi seperti limbah }\end{array}$ & $\begin{array}{l}\text { - Limbah bahan pokok } \\
\text { energi menumpuk } \\
\text { - Kepedulian penduduk } \\
\text { terhadap lingkungan } \\
\text { menurun, banyak } \\
\text { pembangunan baru }\end{array}$ \\
\hline
\end{tabular}


Muazir, Lestari, Alhamdani, Nurhamsyah / Jurnal Pembangunan Wilayah dan Kota, Vol. 16, No. 2, 120-135 Doi: https://doi.org/10.14710/pwk.v16i2.27417

\begin{tabular}{|c|c|c|c|c|}
\hline No & Kekuatan (S) & Kelemahan (W) & Potensi (0) & Kendala ( $\mathrm{T}$ ) \\
\hline & $\begin{array}{l}\text { desa menghasilkan } \\
\text { bahan pokok } \\
\text { - } \text { Penduduk desa } \\
\text { cenderung sudah } \\
\text { memenuhi standar } \\
\text { keperluan sanitasi } \\
\text { - Sarana dan } \\
\text { prasarana minimal } \\
\text { telah terpenuhi } \\
\text { Tidak ada } \\
\text { pencemaran } \\
\text { lingkungan dan } \\
\text { bencana alam } \\
\text { - Sistem birokrasi desa } \\
\text { sudah sesuai } \\
\text { ketentuan, baik dan } \\
\text { langkap } \\
\text { Hubungan dan } \\
\text { informasi } \\
\text { kepemerintahan } \\
\text { dengan masyarakat } \\
\text { baik dan lancat } \\
\text { Sebagian besar } \\
\text { memiliki media } \\
\text { telekomunikasi } \\
\text { telepon genggam } \\
\text { Masyarakat tidak } \\
\text { asing dengan } \\
\text { internet }\end{array}$ & 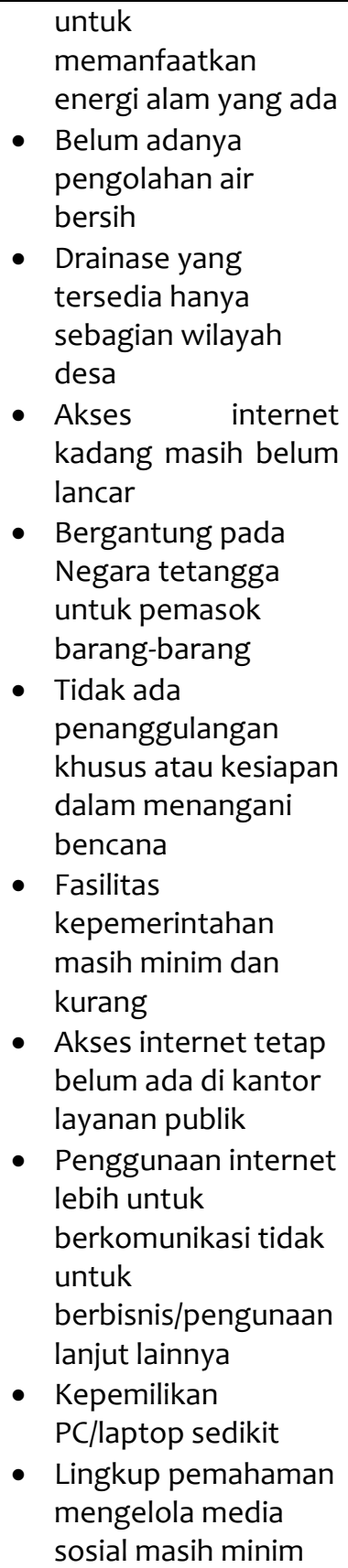 & 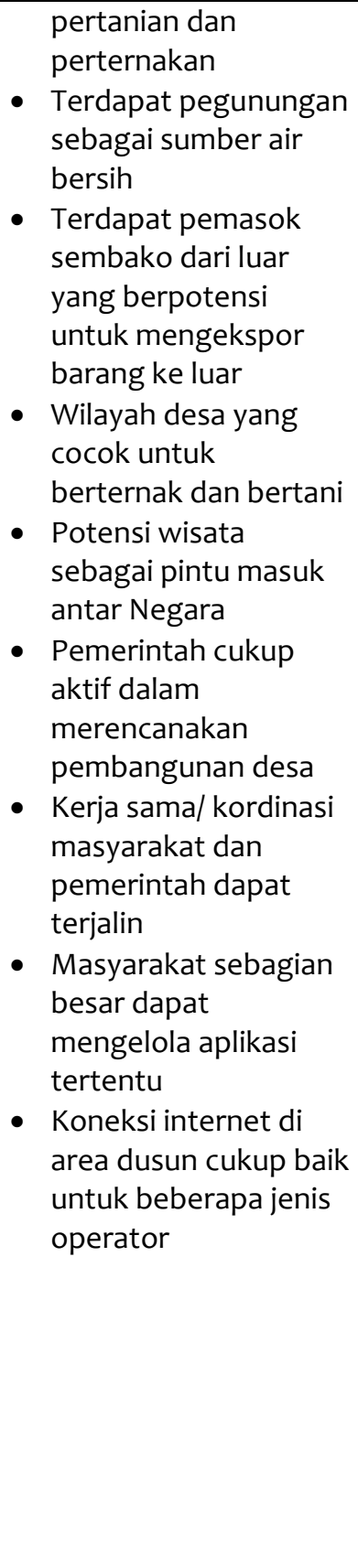 & 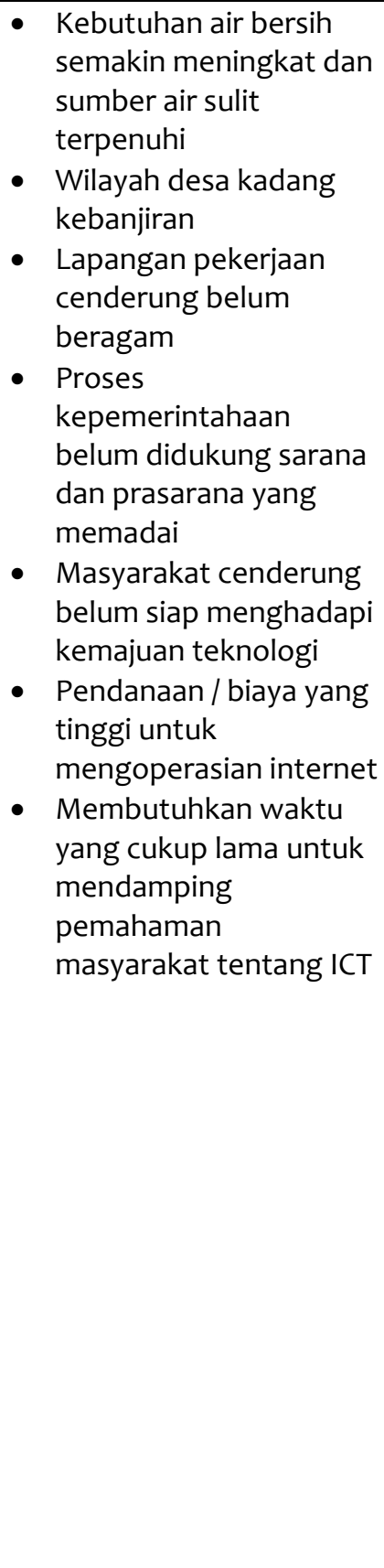 \\
\hline
\end{tabular}

Sumber: Analisis, 2019

Sebagai indikasi strategi/arah pengembangan desa cerdas, beberapa studi kasus desa Cerdas diambil melalui referensi (pustaka) dari desa yang tersebar di tiga negara seperti Indonesia, Malaysia dan India. Di Indonesia terdapat beberapa desa dengan pendekatan yang berbeda seperti Desa Hargotirto yang menerapkan smart tourism, Kabupaten Kulonprogo yang menerapkan smart economy, smart governance, dan smart living berdasarkan kajian Purwanto dan Permadi. (2019). Di Malaysia terdapat satu yaitu Ks Besting yang berupa rekomendasi rencana implementasi desa cerdas berdasarkan kajian Razak et al (2013). Serta, di India terdapat satu desa yaitu Ragihalli panchayat berdasarkan kajian Ramachandra et al (2015). Adapun beberapa strategi yang dapat dikembangkan adalah sebagai berikut: 
1. Mengembangkan iklim "cerdas" dengan pengelolaan yang terpadu melalui system konvesional serta digital, seperti pemasaran, pengelolaan keuangan, serta media social

2. Mengembangkan produk-produk lokal untuk konsumsi sendiri maupun dijual yang didukung oleh sistem marketplace secara online

3. Mengembangkan smart governance yang berupa penggunaan teknologi informasi dan telekomunikasi untuk penyelenggaraan pelayanan publik. Pengolahan data dan informasi yang ada didalam sistem selanjutnya digunakan untuk mengembangkan produk lokal dan potensi wisata

4. Mengembangakn smart living yang bertujuan untuk keterbukaan informasi serta akses informasi dalam kehiudan sehari-hari, misalnya kesehatan, keamanan, dan pelayanan publik

5. Inisiasi pengembangan desa cerdas dapat dilakukan melalui beberapa tahapan seperti: (1) pemberdayaan masyarakat melalui literasi, pengenalan potensi, membangun keahlian teknologi dan promosi (2) pengembangan sistem desa cerdas melalui peningkatan pengetahuan berkelanjutan serta kerjasama dan partisipasi pihak-pihak lainnya

6. Mengembangkan sistem-sistem informasi yang berkelanjutan yang membantu memecahkan masalah penduduk serta mendukung pemberdayaan masyarakat melalui sistem informasi yang telah dibentuk melalui keikutsertaan masyarakat dalam pengembangannya

Berdasarkan atas beberapa "kata kunci" utama dari penilaian literasi ICT, pilar desa cerdas, serta kondisi SWOT yang ada, yang di relevansikan dengan kesempatan-kesempatan pengembangan berdasarkan studi kasus diatas, indikasi strategi awal dalam mengembangkan desa cerdas di perbatasan dapat dilakukan melalui beberapa langkah sebagai berikut:

Tabel 5. Indikasi Strategi Pengembangan Desa Cerdas Perbatasan

\begin{tabular}{|c|c|c|}
\hline No & Kondisi Desa/Dusun & Indikasi Strategi \\
\hline 1 & $\begin{array}{l}\text { Masih rendahnya literasi ICT } \\
\text { masyarakat }\end{array}$ & $\begin{array}{l}\text { Pemberdayaan masyarakat melalui literasi, pengenalan potensi, } \\
\text { membangun keahlian teknologi dan promosi }\end{array}$ \\
\hline 2 & $\begin{array}{l}\text { Pengembangan infrastruktur yang } \\
\text { telah memadai }\end{array}$ & $\begin{array}{l}\text { Mulai mengembangkan iklim “cerdas" dengan pengelolaan yang } \\
\text { terpadu melalui system konvesional serta digital, dapat dimulai dari } \\
\text { pelayanan publik sampai pada kehidupan sehari-hari (smart living) }\end{array}$ \\
\hline 3 & Kondisi lingkungan yang masih alamiah & $\begin{array}{l}\text { Mengembangkan atraksi wisata berbasis web, khususnya untuk } \\
\text { informasi dan promosi }\end{array}$ \\
\hline 4 & $\begin{array}{l}\text { Kompetensi aparatur sipil Negara yang } \\
\text { telah baik mengelola/ menyampaikan } \\
\text { pelayanan publik }\end{array}$ & $\begin{array}{l}\text { Mulai mengembangkan iklim "cerdas" dalam pelayanan public } \\
\text { dengan pengelolaan yang terpadu melalui system konvesional serta } \\
\text { digital }\end{array}$ \\
\hline 5 & $\begin{array}{l}\text { Belum maksimalnya pemanfaatan } \\
\text { energi/produk lokal hasil luaran produk } \\
\text { pertanian/peternakan dari masyarakat }\end{array}$ & $\begin{array}{l}\text { Mengembangkan produk-produk lokal untuk konsumsi sendiri } \\
\text { maupun dijual yang didukung oleh sistem marketplace secara } \\
\text { online }\end{array}$ \\
\hline 6 & $\begin{array}{l}\text { Masih rendahnya sumber daya dan } \\
\text { fasilitasi sosial ekonomi masyarakat }\end{array}$ & $\begin{array}{l}\text { Mengembangkan pemberdayaan masyarakat melalui sistem } \\
\text { informasi yang telah dibentuk melalui keikutsertaan masyarakat } \\
\text { dalam pengembangannya. Selain itu, juga dapat ditingkatkan } \\
\text { fasilitasi literasi teknologi (ICT) }\end{array}$ \\
\hline
\end{tabular}

Sumber: Analisis, 2019

Dari temuan-temuan diatas, perlu juga digarisbawahi bahwa literasi masyarakat yang masih cukup rendah, sehingga korelasinya akan sangat berpengaruh dalam penerapan "konsepsi" desa cerdas. Dalam beberapa diskusi disampaikan bagaimana kesiapan penerapan desa cerdas terkait dengan kesiapan kiounitas masyarakat desanya. Disampaikan oleh Ahlawat (2017) pengembangan desa cerdas dapat dilakukan dengan pendekatan Teknologi Informasi dan Komunikasi (TIK) yang sesuai dengan kondisi geografis yang ada dan infrastruktur eksisting, serta didukung dengan kemungkinan-kemungkinan hubungan antar wilayah sekitar agar terjadinya perdagangan. Pada kondisi sekarang, penggunaan telepon genggam (ponsel) telah menjadi hal yang umum pada masyarakat, bahkan dipedesaan. Sehingga dalam penerapan konsep "desa cerdas" penggunaan ponsel dapat menjadi hal yang penting dalam menerapkan 
aplikasi-aplikasi desa cerdas karena mudah untuk digunakan oleh masyarakat desa. Karena disampaikan oleh Pwc (2017) salah satu tantangan yang ada dalam menerapkan desa cerdas adalah membuat "teknologi" menjadi dapat diakses dan digunakan oleh masyarakat. Isu kemudahan penerapan teknologi juga menjadi pertimbangan utama dalam penelitian Razak dkk (2013) Dalam beberapa penelitian didapati bahwa kemampuan adaptasi teknologi, termasuk ketidakmampuan masyarakat untuk menggunakan teknologi merupakan evaluasi utama program desa cerdas berhasil atau tidak. Dalam mendukung penerapan desa cerdas di komunitas desa, menurut Shukla (2016) pendidikan bagi kaum muda di desa sangat diperlukan untuk dimulai guna mempersiapkan penerapan konsep desa cerdas. Untuk itu, peningkatan-peningkatan kualitas pendidikan dan literasi TIK sangat diperlukan dan menjadi titik "berangkat" utama untuk memulai konsep desa cerdas.

\section{KESIMPULAN}

Dari beberapa temuan diatas, didapati bahwa di dusun Aruk secara umum telah mempunyai skor yang TINGGI dalam indikasi penilaian pilar desa cerdas. Pilar desa cerdas ini mempunyai beberapa kategori dalam penilaiannnya seperti infrastruktur, energi, sosial budaya, dan lain-lain. Namun apabila dilihat secara khusus megenai kesiapan literasi/Melek ICT pada masyarakat, penilaian mempunyai skor yang RENDAH, mengingat beberapa indikasi penilaian hanya di fokuskan pada kondisi literasi masyarakat mengenai ICT, khususnya penerimaan/penyampaian informasi melalui beberapa media. Namun, untuk menuju pengembangan desa cerdas melalui penilaian pilar desa cerdas, dusun Aruk telah mempunyai modal dasar dibeberapa kategori, seperti infrastruktur dan kompetensi aparatur sipil negara. Pengembangan dusun Aruk selanjutnya dapat dilakukan pada sektor-sektor sosial dan ekonomi serta kesiapan masyarakat dalam penggunaan teknologi, khususnya ICT. Lebih lanjut, perlu didorong usaha-usaha pendampingan masyarakat untuk "mempersiapkan diri" menggunakan dan pengelolan infrastrktur yang telah ada serta mempersiapkan diri untuk menggunakan teknologi pada khususnya untuk mendukung penerapan konsep desa cerdas yang pada nantinya dapat membantu pengembangan desa dan pemberdayaan masyarakat.

\section{PERNYATAAN RESMI}

Artikel ini merupakan bagian dari hasil Penelitian Dasar yang dibiayai oleh Dikti (Kemenristekdikti) tahun 2019

\section{DAFTAR PUSTAKA}

Agus Purwanto., Dedy Permadi, E. (n.d.). Desa Cerdas: Transformasi Kebijakan dan Pembangunan Desa Merespon Era Revolusi Industri 4.o. Yogyakarta : Center for Digital Society.

Ahlawat, J. (2017). Smart Villages, Information Communication Technology and Geographical Information System. International Journal of Current Trends in Science and Technology Smart Villages , Information Communication Technology and Geographical Information System. 7, 20232-20238.

Borsboom-Van Beurden, J., Kallaos, J., Gindroz, B., Riegler, J., Noll, M., Costa, S., \& Maio, R. (2017). Smart City Guidance Package for Integrated Planning and Management: Planning and implementation of Smart City projects: phases, common obstacles and best practices, key performance indicators, upscaling, and replication. Action Cluster Integrated Planning. June, 80. https://eu-smartcities.eu/sites/default/files/2017-09/SCGP Intermediate version June 2017.pdf

Burhan. (2015). Remaja Desa dan Teknologi Informasi Kabupaten Buton. Shautut Tarbiyah, Ed. Ke-32 Th. XXI, Mei 2015. $17-36$.

Catts, R., \& Lau, J. (2008). Towards Information Literacy Indicators: Conceptual Framework Paper. Paris, France: UNESCO.

Covello, S. (2010). A review of digital literacy assessment instruments. Syracuse University, 1-31. http://www.apescience.com/id/wp-content/uploads/DigitalLiteracyAssessmentInstruments_Final.pdf

Fennell, S., Kaur, P., Jhunjhunwala, A., Narayanan, D., Loyola, C., Bedi, J., \& Singh, Y. (2018). Examining linkages between Smart Villages and Smart Cities: Learning from rural youth accessing the internet in India. 
Telecommunications Policy, 42(10), 810-823. https://doi.org/10.1016/j.telpol.2018.06.002

Indira, C. G., \& Anupama, V. (2016). The Smart Villages: The Real Future Of Emerging India. International Journal of Innovative Research in Advanced Engineering (IJIRAE), 3(12), 29-31.

Johnson, G. M., \& Johnson, G. M. (2007). Functional Internet Literacy : required. 4(4), 433-441.

Krejcie, R, V., \& Morgan, D, W. (1970). Determining Sample Size for Research Activities. Educational and Psychological Measurement, 30, 607-610

Muazir, S. (2016). Applying Adaptive Network Urbanism to Improve Strategic Areas in Sambas Regency, West Kalimantan, Indonesia. https:/www.airitilibrary.com/Publication/alDetailedMesh?docid=Uoo260608201617315600

Nick, G. A. (2016). Correlation between European Smart Cities and Regional Competitiveness. Scientific Proceedings International Scientific Conference "Industry 4.0," 2, 45-49. http://industry4.eu/winter/sbornik/2016/2/12.CORRELATION BETWEEN EUROPEAN SMART CITIES AND REGIONAL COMPETITIVENESS.pdf

PwC. (2017). An ICT approach to rural metamorphosis: A white paper. PriceWaterhouse Coopers Rural Metamorphosis Report, 2, 1-30.

Ramachandra, T. ., Hegde, G., M.D.Chandran, S., Swamiji, V., \& Kumar, T. A. (2015). SMART Ragihalli : Effort towards S elf-reliant \& Self-sufficient system empowering $M$ an power (rural youth ) with A ppropriate $R$ ural T echnologies ( Ragihalli Gram panchayat adopted by Shri Ananth Kumar, Member of the Parliament, Bangalore South , und (Issue June 2017). https://doi.org/10.13140/RG.2.1.3615.6646

Razak, N. A., Malik, J. A., Saeed, M. (2013). a Development of Smart Village Implementation Plan for Agriculture: a Pioneer Project in Malaysia. Computing \& Informatics, 4Th International Conference, 2013, 024, 495-502.

Shukla, P. Y. (2016). The Indian smart village : Foundation for growing India. International Journal of Applied Research, 2(3), 72-74. www.allresearchjournal.com

Somwanshi, R., Shindepatil, U., Tule, D., Mankar, A., Ingle, N., Rajamanya, G., \& Deshmukh, A. (2016). Study and development of village as a smart village. Int. J. Sci. Eng. Res, 7(6).

Wahyono, S, B., Pujiriyanto. (2010). Analisis Jalur Terhadap Tingkat Melek Teknologi Informasi Dan Komunikasi (Ict Literacy) Pada Mahasiswa FIP UNY. Laporan Penelitian Fakultas FIP UNY 